\title{
Money and Finance in the Wealth of Nations: Interpretations and Influences
}

\author{
Mariano Castro-Valdivia \\ University of Jaén, Jaén, Spain
}

\begin{abstract}
The paper analyzes the classical approach of the money and finance in the cited work of Adam Smith. Specifically, it studies the spread of these ideas in Spain in the late 18th and early 19th century. To do this, the above on this matter is investigated in the two editions that Alonso José Ortiz made of that work. In addition, their influence is discussed in the first Spanish edition of the Treaty of Political Economy by Jean Baptiste Say, translated by José Maria Queipo de Llano y Ruiz de Sarabia, 7th Count of Toreno. It should be remembered that it was a reference work for academic training in the chairs of political economy. In 1807, Plan Caballero, created in the Faculties of Law. Finally, it explains the influence that had the Smithian approach on this issue in the work of Ramón Lazaro de Dou y de Bassóls and Edualdo Jaumeandreui Triter.
\end{abstract}

Keywords: money, teaching economics, classical school

This paper is a study on the evolution of the concept of money in the principal text books used for teaching economics from the mid-eighteenth century to the early nineteenth century. Handbook of Genovesi, Condorcert, Smith, Herrenschwand, Canard, Say, Dou, and Jaumeandreu are studied in the following sections.

The Wealth of Nations (1776), Adam Smith, is a land mark in modern economics. It was the first manual agglutinated economic thought of what is known as classical economics. On the other hand, the approach of this work, as indicated by Murray Newton Rothbarb (1995), it is almost the same as presented lessons. $A$ System of Moral Philosophy (1755) by Francis Hutcheson (1694-1746), is a work edited posthumously by his son in Glasgow. Specifically, the subject of this article, Hutcheson laid the foundations of the dissertation on this subject. His analysis of what could be the most appropriate to fulfill the function of money goods, the definition of money, price formation, etc., were used as a guide for subsequent treaties on this matter. Hutcheson argued that:

Money, (...) is a commodity generally accepted in a particular country that becomes used as general medium of change, and as a common standard of value and measure for economic calculation. Commodities which are chosen as money on the market are those with the most money-ish qualities: already generally desirable an acceptable in exchange; divisible into small quantities without losing their pro rata share of value; durable for long periods of time; and portable, for which quality they must have a high value per unit weight. Generally, (...) silver and gold have been the two commodities that have been chosen as by far the most suitable as money, with coins becoming the most popular form precisely for being divisible and easily carrying a warrant of purity. (Rothbard, 1995, p. 421)

Corresponding author: Mariano Castro-Valdivia, Ph.D., professor, Department of Economics, University of Jaén; research fields: the teaching of economics at Spanish University of the 19th century and the influence of Jean-Baptiste Say in the formation of classical economic thought in the first third of the 19th century. E-mail: mcastro@ujaen.es. 
In the Spanish case, Hutcheson's work was used as a reference handbook in the Real Seminario de Nobles de Madrid since the mid-18th century (Soubeyroux, 1995). From 1779, the work of Bernardo Joaquín Danvila y Villarrasa (1745-1782), professor of moral philosophy and public law of the Real Seminario de Nobles de Madrid since December 1, 1774, was used as a handbook (Cervera Ferri, 2008). Las Lecciones de Economía Civil, óde el comercio, escritas para el uso de los caballeros del Real Seminario de Nobles, the work published in Madrid in 1779, tackled the matter discussed in Lesson VII (Danvila Villarasa, 2008, pp. 141-149). Entitled De la moneda, Danvila, as well as Hutchenson, he explained that goods were used as money before the coin age of gold and silver. Just how useful it was for human society since the invention of money. What were the functions of money as a medium of exchange and unit of account, as its circulation increased the wealth of a nation, an idea taken from Genovesi (Cervera Ferri, 2008). He concluded his presentation by analyzing the paper currency as a financing tool and the institutions that generate it, the bank.

On October 24, 1784, began operating the first Chair of Economics of Spain. The Real Sociedad Económica Aragonesa de Amigos del País requested, the July 28, 1784, Carlos III established a Cátedra de Economía Civil y Comercio in Zaragoza, similar to the one that the king had authorized in Naples in 1754, and Abbe Antonio Genovesi executed until his death in 1774. The Dr. Lorenzo Normante y Carcavilla (1759-?), teacher of the Cátedra de Economía Civil y Comercio from its creation to 1801, initially, he taught with handbook's Danvila. This manual was recommended until it was translated into Castilian Delle Lezioni di Comercio o'ssia di Economia Civile (1765-1767) of Genovesi. Starting from his translation, by Victorian Villava between 1785 and 1786, and during the rest of the 18th century, lessons were used as a reference text for teaching in this chair and other institutions that explained economy in this period. Ramón de Salas (1754-c.1837) used it in the Academia de Leyes de la Universidad de Salamanca and José Antonio Mon de Velarde in the Academia de Economía Política de la Real Sociedad Económica Mallorquina (Castro-Valdivia, 2012). Between the last decade of the 19th century and the first of the 19th century, the monopoly of Genovesi was broken, other works were used to teach economics, from the Spanish versions of Condorcet and Alonso Wealth of Nations Smith, works of Herrenschwand and Canard were translated. Later, with the creation in 1807 of the Chair of Political Economy at the Spanish universities Say's Treaty, which monopolized the teaching of our discipline during the next three decades, was used.

\section{Antonio Genovesi (1712-1774)}

Lecciones de comercio, ó bien de Economía Civil (1785-1786) is the Spanish version of the Lezioni by Genovesi ${ }^{1}$. The translation of Victorian Villava was based on the Neapolitan second edition (1768-1770) of this work. The first Spanish edition of the book was published in three volumes (the first volume: p. 22, p. 279; the second volume: p. 187; and the third volume: p. 351) between 1785 and 1786 in the printing of Don Joachin Ibarra de Madrid, under the title Lecciones de comercio, o bien de economía civil. In 1804, there was a reprint, also in three volumes, in the press of Don José Collado de Madrid, editing serving as a reference for this study.

The Spanish version of the Lecciones is an annotated translation, which begins with an introductory speech by the translator (Genovesi, 1804, pp. 1-12), in which he exhibited and appreciated the outline of the work, noting that he was going to explain some top notes defended by Genovesi, though, in our opinion, Villava only made some very significant clarifications. He also commented that although the text content was

${ }^{1}$ For further information on this subject see the work of teachers Astigarraga and Usoz (2008). 
not original and it followed the English model, it was very educational to read, because he had ordered and correctly summarized the principles of political-economic systems discussed by these authors, which made Lecciones one good manual for the teaching of economics among the youth, who according to the author the book is addressed.

Throughout the text, are numerous quotes, especially classical authors mainly Plato, Aristotle, and Homer, and contemporary authors such as Becaria, Bielfeld, Bodino, Campomanes ${ }^{2}$, Cary, Filanghieri, Galiani, Obbes—Hobbes—, Hum — Hume—, Mandeville, Melon, Moncada, Montesquieu, Muratori, Neker, Puffendorf, Rouseau, Turgot, Ulloa, Ustariz-Uztariz — , to name a few, that throughout the text are appointed. On the other hand, a big number of travel books and history of countries that the author used for exhibition and that gives us a comparative analysis between nations for some matter.

The Genovesi's manual presents two parts. The first: Two tomes analyze in 22 chapters, the general principles of civil economics. The second, comprising of 13 chapters, treats various monetary and forms a handbook on the currency, which the author will summarize below.

It begins, as almost all treaties of this subject with a theory of price formation. Genovesi considered that all the concepts related to this matter: price, value, estimation, pose, should be understood in relative rather than absolute terms, since it did not indicate the intrinsic value of things, but the relationship between them. In civilized countries to facilitate trade in goods a commodity as a rule or measure other established: money. Therefore, these terms reflect the existing relationship between the goods in cash and variation of these relationships, which are determined by human needs, which are the source of value of all things, while the price of goods shows "el poder que tienen de satisfacer nuestras necesidades" (Genovesi, 1804, p. 8) depending on the abundance or lack of these. He justified the paradox of value.

Regarding the pricing of goods in exchange, the Neapolitan clearly exhibited a competitive market mechanism, where the forces of supply and demand determined the situation:

Cuando las necesidades menguan, y las cosas que las satisfacen no, se disminuye el precio de ellas, porque siempre se aprecia menos aquello que menos se necesita y al contrario, sin son mayores nuestros menesteres, y la cantidad de las cosas es la misma, sube su precio por la misma razón. (Genovesi, 1804, pp. 11-12)

So that the author considered the existence of a relationship made in the price of goods, maintaining a direct relationship with the needs and durability of good and inversely with the existing amount thereof, which explained the paradox of value. On the other hand, he noted that the prices of things could change for two other external causes: taxes and the amount of gold and silver existing in a country. He also indicated that the prices of goods varied according to the amount that was put into circulation, so that if the goods are extracted, was the same as if they did not exist, and therefore the price of goods increased. Therefore, the state should pursue such behavior.

His dissertation on the currency continued the explanation of why gold and silver were used as such. So, he called precio eminente to goods acquired this nature. The value of the currency is based on the value of the metals used in coin age, and inseparable from it. The currency had three values or prices. The first was the intrinseco, the value of your stuff, because it was composed of the inverse of the quantities and direct needs. The second was the legal y extrinseco, tax by the sovereign, who not long departed from the value of the subject, unless reasons of state demanded it and is known by patron fiduciario. The third was the de la

${ }^{2}$ References to this author only are found in translator's notes. 
comodidad, which reflected its value use in commerce, he called rédito, interés, premio, o usura del dinero, also showed an inverse ratio to the abundance of currency and direct trade or need to use. The coin was a wealth, not absolute and primary and secondary but representative, which could be defined as:

Un pedazo de metal determinado peso y bondad, que tiene un nombre y valor conocido, que se halla sellado con la imagen y las armas del Soberano, y que sirve de instrumento para medir el valor de todos los géneros y todas las obras con que puede comerciarse. (Genovesi, 1804, p. 39)

Our author pointed out some practical proposals on the currency. First, the value of this could not depend on the discretion of individuals; second, the prices of things in relation to the currencies should be established either by sheer will; third, that when the price of the goods, or value for money, does not respect the expressed proportions disappear gender or money hoarded; fourth, pricing by the cities produced in the medium term the ruin of their trade; and fifth, if the amount of salable things, grows the value of money and contrary (Genovesi, 1804, pp. 46-48).

As for the role of banknotes or paper representing the currency, that is the currency in circulation, said that was introduced by increased trade and ease which involved use in transactions over long distances, not having to move currency. In his presentation, he made a brief historical reference to their origin: issuance in 1171 of the first banknotes in Venice, and noted that its overabundance could be harmful, because there would come a time when this representative wealth exceeds the value of real wealth producing in this case as low down in circulation (Genovesi, 1804, pp. 55-62).

Regarding public credit commented that without it, the trade would not work. In general, credit was the ability to use and rely on other people's property as their own, justify in this section the need for companies to trade because of these trade was based and without them it would be difficult to build the public credit. Finally, he said that this credit system may not last long term (Genovesi, 1804, pp. 62-85).

He also discussed how the circulation strengthened the currency. First, he analyzed the advantages and disadvantages of money. He also said the contempt classical authors, Aristotle and Plato, had the thought that generated vices, false opinions and a new social class: rentiers, living without working and enriched the work of others. All this was an increase of stimulus own, and produced fraud, injustice, and monopolies, but felt better use sparingly and teach mankind had to do with money for the happiness and that of others. On the other hand, Genovesi highlighted the benefits and how that money favored the state. In particular, he noted that the currency facilitated trade and the arts, citing the famous dictum of Hume on the subject:

(El dinero es...) el sebo con el que se untan las ruedas del carro para hacer más expedita la rotación, y apresurar su movimiento. Despierta en el corazón humano una cierta energía inexplicable, la qual da mayor actividad a las fatigas, y mayor velocidad a las permutas, aquella aumenta la quantidad de acción, y ésta el despacho. (Genovesi, 1804, p. 104)

Therefore considered that in every country, the state of the industry was directly related to the mass of money, and the things he represented. He also noted that to achieve this beneficial effect of currency, we should get an equal and equitable distribution thereof, and circulation. To reach this objective, the country should conduct a division of the land as equal as possible and establish a full liberty in trade. As for the movement of both genders and money, said they were intrinsically linked, since one could not exist without the other. Therefore, we had to stoke the turn of the goods to make money faster and, conversely, facilitating the circulation of money to increase the rate of exchange of genres, representing a rudimentary approach to quantitative theory. He also said that countries with greater circulation would be richer. For Genovesi, causes 
that increased circulation were: increasing needs, generating surpluses, the existence of a legal nature that ensured the above, etc., if the author said was on the contrary, decreased circulation occur. On the subject of usury, it defined it as "el precio de la comodidadque le resulta al que lo toma" (Genovesi, 1804, pp. 188-189), that is, the premio del dinero. Furthermore, he commented the relationship between usury and commodities exchange. On the other hand, el precio de la comodidad, it was as all other things interchangeable trade revolve in reverse to the right amounts of genres, and direct needs.

Following the above, the last definition which gives the coin in the text is very synthesizer:

(...) riqueza secundaria, cuya fuerza es igual a la potencia representativa de las riquezas primitivas: su uso se dirige a hacer girar con mayor velocidad los frutos y las manufacturas. (...) el dinero no debe exceder de esta cantidad de riquezas representativas. (Genovesi, 1804, p. 287)

\section{Marie Jean Antoine Nicolas de Caritat, Marqués de Condorcet (1743-1794)}

Compendio de la obra inglesa intitulada riqueza de las naciones (1792) translated from French into Castilian by Carlos Martinez de Irujo and printed in the Realprinter of Madrid. This work was published in 1790 by the Marquis de Condorcet inisde the "Bibliothèque de l'homme public, ou analyse raisonnée des principaux ouvrages françois et étrangers sur la politique en général, la législation, les finances, la police..."- third and fourth tomes, in the Buisson Printer of Paris.

This book contains the author's comments on the An Inquiry Into the Nature and Causes of the Wealth of Nations by Smith, being it a summary of the work. This essay is divided into five chapters, corresponding to the five books that have such work, and comment on each of them, the main ideas of the book, valuing grounds and opposing certain claims of British author.

The Spanish version of this work begins with an introductory speech by the translator in eleven pages, justified the need for translation, and presented the mainline of the work. Specifically, it gave a brief summary which summarized very clearly the purpose of Smith's work:

(...) libro $I^{o}$. las causas de los progresos del trabajo, y el órden y medios por donde su producto se va distribuyendo naturalmente entre todas las clase y miembros de la sociedad. De la distribución de las tareas nace precisamente la diferencia entre los empleados útilmente, y los que no tiene una ocupación productiva; y como el número de los primeros es siempre proporcionado al fondo, ó capital que se aplica al trabajo, y al modo de hacer esta aplicación, trata el Autor en el libro II'. De la naturaleza de los capitales ó fondos, y de la diversidad de ocupaciones que resultan según el diferente modo de emplearlos.

Casi todas las naciones han tomado rumbos diferentes para llegar a la prosperidad á que aspiraban: unas han fomentado la agricultura, otras han favorecido la industria; pero desde la decadencia del Imperio Romano esta ha conseguido una protección particular. El Autor entra en las causas de esta preferencia, y presenta en el libro III ${ }^{\circ}$. Los pasos por donde ha venido á lograrla. Esto le lleva naturalmente a examinar las diferentes teorías sobre la industria y la agricultura, y emplea todo el libro $I V^{\circ}$. En explicarlas y demostrar sus principales efectos.

(...) libro $V^{o}$. De las rentas públicas, y de las del soberano. (...) explican quales son los gastos del Soberano, ó del pueblo, los que deben cubrirse por medio de una contribución general y los que solo por una particular; los medios mas propios para hacer iguales las contribuciones; las ventajas é inconvenientes de estos diferentes medios; y finalmente trata de las deudas públicas, y de la influencia que han tenido en la riqueza de los estados. (Condorcet \& Marquis de, 1792, pp. 7-9)

Condorcet's essay explained the main idea of the origin of the wealth of Smith, which revolved around work cone source of all the wealth of nations and in his division, this being responsible for increasing the production of goods, which turn generated the universal opulence. The principle of the division of labor was 
essential in Smith's argument, it allowed to increase the skill and agility of each operator, save time regularly lost going from one occupation to another and encouraged the invention of machines that increased productivity work. As for the origin of the division of labor, he speculated that this was a necessary consequence of human nature, and we liked that we had to change so it was not in our power. Therefore, the inclination to trade is the source of the division of labor, that is, there is a direct relationship between the division of labor and trade.

He continued his analysis to the study of the use and origin of the coins. In particular, he explained that the ongoing conflicts to verify exchanges ${ }^{3}$ necessitated the introduction of goods that could be easily changed: oxen, salt, etc., although humans agreed to give preference to metals ${ }^{4}$. These were minted to facilitate changes, encourage industry and trade, so that money - the coin — became the general instrument of trade between civilized nations. So a new concept of value is introduced: el valor de cambio o relative, who was the proportion of money given in exchange for a product ${ }^{5}$, where cash price of all goods, the components of such rates and the circumstances that made raise or lower prices, explained el valor de cambio the goods.

He also discussed whether or not the use of bank money and its related-letras de cambio, etc., noting that the use of notes instead of gold and silver increased the circulation of money and goods, well, increased the value of the annual produce of the land and labor, but warned that only this type of money render as exposed if was backed by gold and silver deposits in issuing banks paper money - Condorcet described the functioning of Depository Bank of Amsterdam, such a way that a decompensation in said ratio, between deposits and banknotes, produces more disadvantages in the economy of a country than advantages. What really encouraged the industry of a nation was not the capital increase, but to make it productive, minimizing fondos muertos, justifying this behavior in the double value — use - that money was for people: maintenance of wealth and means of payment.

\section{Adam Smith (1723-1790)}

The work of Smith An Inquiry Into the Nature and Causes of the Wealth of Nations (1776) published in London in two volumes by W. Strahan and T. Cadell, it was translated by don José Alonso Ortiz of its eighth edition ${ }^{6}$. Impresa en 1794 bajo el título de Investigación de la naturaleza y causas de la riqueza de las naciones. Obra escrita en Inglés por Adam Smith, Doctor en Leyes, é Individuo de la Real Sociedad de Londres $y$ de Edimburgo: Comisario de la Real hacienda en Escocia: y profesor de Filosofia moral en la Universidad de Glasgow. La traduce al castellano el Lic. D. Josef Alonso Ortiz, con varias Notas é Ilustraciones relativas á España, in four volumes, in printer of the Widow and Sons of Santander in Valladolid. In the early 19th century, The Wealth of Nations was published in Castilian again. In Valladolid, between 1805 and 1806, the printer of the Widow and Sons of Santander, the same who had published in 1794, published a revised and expanded version of Josef Alonso, also its first edition in four volumes. The differences of this edition with the previous

\footnotetext{
${ }^{3}$ The problems to match the needs of individuals, changing their surplus and the difficulties in establishing the number of objects to be exchanged, to maintain a fair and an accurate rate of change.

${ }_{5}^{4}$ These were chosen for their ease of storage, durability, and divisibility.

${ }^{5}$ On the other hand, the traditional sense of the term value or usefulness meant the advantage we got from one thing, and was known for el valor de utilidad.

${ }^{6}$ As he indicated in hiswork: "hemosarreglado la nuestra a la ediciónoctava y últimaque se ha dado del original" (Smith, 1794, last page of the warning translator; Smith, 1805-1806, last page of the warning translator). This seems doubtful after consulting various catalogs and monographs on various English editions of The Wealth of Nations, the last edition that might be used for translation Alonso was the seventh, published in London in 1793.
} 
are minimal in spite of what was announced by the translator in the title of the work. Therefore, this second edition can be considered more as a reissue than a new edition.

Smith investigated the currency in the fourth chapter of the first book. He began by noting that an individual produces very little compared with what it was needed, such a way that to cover most of your needs should exchange the surplus product of their work by others. This process, barter, it was quite complicated so that humans needed to adapt a product as money that facilitates the exchange. He explained the process that led to humanity coinage of gold, silver, and other metals, which increased the circulation of goods and progress of human society. He made a brief historical reference to the different values that the coins had in England and France $^{7}$, concluding that the devaluation of the coins was beneficial to the debtor, while it was hurtful to the creditor.

He described the different types of paper money and its operation. Replacing gold coin and silver paper was an improvement, banknotes being it the best kind of paper money, because its emission reduced the need for gold and silver needed to trade in the country, generating excess thereof. These could be sent abroad and exchanged for goods, promoting a new fund to increase trade, and consequently the income of the nation, said the functioning of Bank of England and the operación de levantar dinero por circulación ${ }^{8}$.

Therefore, banking increased the economic activity of a country, becoming unproductive capital into productive traders, but made the trade and industry have greater uncertainty. Hence, it was necessary to take precautions to avoid most of the circulating capital of a country was paper money. The circulation in any country should be considered in two branches: one that took place between traders and that was between merchants and consumers. Establishing a restriction on the movement of the first that should not exceed the value of the use of the latter, on the other hand, considered inappropriate use of small bills, since in his view that the modest encouraged people to become bankers. For Smith, the only restrictions paper money should be two: Not issue bills of low denomination and that all are paid in sight.

\section{Jean Herrenschwand (1728-1811)}

The main work of this Swiss economist, Principios, was published in 1786 by Hookhan in London. Its author wrote it in French under the title of "De l' économie politique moderne. Discours fondamental sur la population". In Spain, Juan Smith translated this work under the title of "Principios de economiapolitica", which was published in Madrid by Vega and Printing Company in 1800. The Spanish version began with a brief warning about the timing of publication of the original work. The translator considered this necessary information, as the reader may misunderstand the work to the changes in Europe since the publication of the original to this translation.

The work is a discourse analyzed, as the subtitle, 274 pages without division, or parts or chapters, which mainly analyzes the matter of the population, but that explains other economic issues. Among them, the author analyzes the issue of interest on money. For it, he made a brief presentation on his concept and what happened when the money was borrowed. Distinguished two classes of policyholders: Those destined for the loan to purchase goods - land and manufactures — in order to consume, nonprofit; and buying goods in order to earn

\footnotetext{
${ }^{7}$ Alonso supplemented this information with an extensive footnote on page with the evolution of the different values of coins that circulated in Spain from the Visigoth times to the Bourbon (Smith, 1794, Tome I, pp. 41-46; Smith, 1805-1806, Tome I, pp. 423-426).

8 Operation explained in Section III of Chapter II of Book II (Smith, 1794, Tome II, p. 56; Smith, 1805-1806, Tome II, p. 165).
} 
money from their sale. The former is called consumers; traders, businessmen, and landowners manufacture the latter. He also noted two kinds of interest: the law or legal and square or market, known as current. The first was determined by the government, being the highest price at which it was allowed to give or borrow, while current interest was determined by competition existed in the market (Herrenschwand, 1800, pp. 124-125).

On the other hand, he noted the existence of a kind of inverse relationship between wages and profit. A second reason he called razóncaracterísticadelsalario a la ganancia de las manufacturas ${ }^{9}$, where the salary was the antecedent of the correlation and the consequent gain. However, he noted that the United States failed to meet the principles set ${ }^{10}$.

It was shown that the rate of interest depended not only on the amount of money circulating in the nation, as many had believed and acted, but also the wage-benefit ratio of manufacturing. In his view, it was clear that the interest of money would always be the consequence and accurate measure of the prosperity of a nation, unless the government intervenes against the natural order. There was an inverse relationship between this prosperity and the interest rate, not the author observed in reality, because the rulers have continued to intervene in the natural course of interest rate fixation with laws, wars, etc. He also commented the belief that prosperity needed short wages which was widespread among the rulers. In his opinion, this idea is wrong, because what should be short, were the profits of entrepreneurs (Herrenschwand, 1800, p. 143).

\section{Nicolás François Canard (1750-1833)}

The work analyzed, Principesd'économiepolitique (1801), was edited by F. Buisson Chez Paris. In Spain, Dr. Francisco Serrano y Serrano translated under the title of Principios de economíapolitica (1804), which was published in Madrid by the Office of the Widow of Lopez and Sons.

The work began with a dedication to the Minister of Finance, without giving his name. It seems that the translation of Francisco Escolar was dedicated to Miguel Cayetano Solery Rabassa, who led the Secretary of State and the Universal Office of Finance of Spain and the Indies from September 1798 until March of 1808.

Following the dedication, the text continues the author's preface. In this, Canard commented the subject of his work. The land was the only source of wealth of a country farmer and that any contribution should fall on it had been advocated by many economists. Therefore, the National Institute of France proposed to analyze the following maxim: "si es cierto que en un país agricultor las contribuciones todas recaen sobre los propietarios de tierras" (Canard, 1804), the author's work was awarded on January 5, 1801. Canard positioning on the matter is that it was wrong. To justify his position had to analyze the productive sources of wealth and analyze their implications for solving various problems of this science.

In the opening pages is a warning indicating suppression translator calculations and algebraic formulas that existed in the original, Chapters III and VII, considering that it was not necessary for the understanding of the work, and to be able to read by everyone.

The subject of analysis of communication was treated briefly in Chapter II. The money came from the need of trade, because as the author got older, the barter system became untenable, so they had to find a commodity to serve as such. This ideal merchandise must be easily divisible, have a uniform and constant value,

\footnotetext{
${ }^{9}$ Our author emphasized that manufacturing was because, as was generally the same ratio, that is, between farmer and rancher, and this was determined by the first, we were not interested generalized to not confuse (Herrenschwand, 1800, p. 131).

${ }_{10}$ In the American case, wages and moneyed interests were higher than in other countries and this issue was explained that it was a new country expansion devouring resources and raised the cost thereof (Herrenschwand, 1800, pp. 126-127).
} 
be durable and easily transportable. For this reason, it was considered to gold and silver as money commodity. The coinage was a way to ensure its purity, good law, and to further facilitate trade. The currency should not be considered representative of all things, but the intrinsic value of the amount gender permuted being critical to the creation of paper money or bank.

He also studied the circulation of money and credit in Chapter IV. The objective of the analysis was to check their level of need and how its possible replacement of Canard's dissertation is based on the assumption that credit was absolutely nil among men, namely, that no one would work but be given to him a quantity of money equivalent to their work. If there was no credit, all exchanges using hard cash, so that the money supply in circulation was equal to goods circulating.

If credit among men was infinitely large, money was totally useless for circulation, because buyers rather than metal, give sellers a card or note, which would be received as if it were money. This change in the amount of work of equal value, and the role of credit money would be absolutely useless. The tradable things would be much cheaper, because when credit is infinite, only contains the work and the product of territorial revenues, income, and no money. The nations were not in either of these extremes, but all were more or less distant from them. Where there was more credit, the work product was cheaper than where circulation needed to spend much money. The nation that had much credit, and little cash in circulation, was richer.

Do not judge the wealth of a country by the cash flowing, but this and the conjunction, that is the amount of the product of labor and income that ran contrary to money management. The representative value of paper circulating, plus the actual value of the currency, was equal to the current value of all goods and can say that to increase the wealth of an active and industrious nation was best to increase lending.

Canard continued his essay, analyzing the laws of movement, and exposed to the elements, constituting the value of gold and silver were variable, its value could be neither fixed nor constant, so they could not serve as a scale to measure value of all things at different times, although it should be recognized that there was no goods whose value will vary less from nation to nation for its portability and durability over time, so that men have preferred these metals to measure value each work product. Obviously, to compare the value of other things at different times, less variable measure is needed, and Canard proposed using natural or necessary wage, because although its value is suffered some deterioration in his opinion the most stable.

\section{Jean-Baptiste Say (1767-1832)}

The author deals with the question analyzed in the second book of the Treaty ${ }^{11}$, and indicated that the currency facilitated the satisfaction of needs of the individual, and that the latter was more necessary in the countries with a greater degree of civilization and division of work, was divided and work. Also, keep in mind that it has been the custom, and no government authority, which has given the use of currency to a commodity. The coinage of gold and silver complied with features that should have a product to serve money, easy divisibility; it was not a common good; and their value will result unchanging over time or vary as little as possible, that is, that the quantity was more or less stable ${ }^{12}$.

The coin, which some call numerario, was a commodity whose value is established according to the common rules to all others. Therefore, the numerario had a country, part of his wealth, like the rest of genres

\footnotetext{
11 Translated into Castilian work under the title of Tratado de Economía Política o exposición simple del modo cómo se forman, distribuyen y consumen las riquezas (1804-1807).

${ }_{12}$ This question was considered in 12 chapters, from I to XII, Book II of the Treaty (Say, 1804-1807, Tome II, pp. 129-269).
} 
that possesses. The manufacturing process of the coin, coinage or seigniorage, was exclusive to the government of each nation and had a cost, sometimes it was assumed by that government-England, and other non-generally in the rest of Europe was charged for expenses coining or braceage by 5\%. Therefore, the value of the currency was greater in proportion than the same amount of metal stick because facilitated the exchange and not the right of coinage. On the other hand, Say commented it was a mistake that public authority could freely increase or decrease the value of the coins. In general, governments kept the nominal value of its currency but decreased their gold or silver content, so a devaluation of the currency value occurred. This action by governments was known for alza de moneda.

Whether the precious metal content in the currency could be the measure of the value of two different things was a widely debated issue. According to Say, the precious metal was nothing more than a commodity whose value was arbitrary and fitted in each market based on supply and demand, which could not execute the office of measure, whose first badge was to be unchanged, although it was a good approximation of the value of things. Therefore, the method used by historians to update the present value of old coins, based on the amount of gold and silver they contained was not correct.

In the event that the coin was worth anything if not, this would be a sign. Therefore, the intrinsic value of various currencies indicates that these are not a sign showing, if not, rather it really was a sign was a charter bank payable on sight. In conclusion, Say analyzed the various instruments that allowed increase credit of company bills, deposit banks, banks turning the cards of bank and paper money ${ }^{13}$.

\section{Ramón Lázaro de Dou y de Bassols (1742-1832)}

This author published a work of economic character with the title of La riqueza de las naciones, nuevamente explicada con la doctrina de su mismo investigador (1817), printed by a printer of the University of Cervera. This text, as the author in his preface, attempted to clarify gaps Smith's work had generated in Spanish readers.

The work was published in two volumes and divided into six parts. Dou explained his interpretation of the work of Smith and was devoting over the content of some of the books that Smith had ordered his Wealth of Nations. He studied wealth, currency, price formation, the division of labor, and its characteristics. He discussed other matters as the accumulation, the trade system, ground rent, utilities, culture, and taxation. When he saw fit to issue analyzed, copied the text of Smith and performed a dissertation on the subject. Overall it was quite critical of Smith on the issue of international freetrade, as preserved even the theses of the great defenders of Spanish mercantilism: Ustáriz, Ulloa, Ward y Campomanes. On the other hand, as indicated by Almenar Palau and Lluch Martín (2000), Dou has been one of the major transmitters of the thought of Adam Smith in Spain.

As for the money, Catalan economist considered it crucial to understand economics, because after defining what was wealth in the first chapter of his work area, devoted the next three, explain why the coin was the best instrument to acquire wealth and to define the process that occurred gold and silver as suitable for use as money goods. Moreover, analyzes how the value of the currency was altered and as the extrinsic value of this should be consistent with the intrinsic. In addition, studying the difference between currency circulation nationally and abroad. Also indicated that the value of things was not determined by the gold or silver, but by the amount of work that allowed to buy such property. Concluding that the gold and silver did not conform to the wealth of a country, even if there should be enough to allow circulation, as their lack preclude the exchange. However, also

${ }^{13}$ Each of these instruments wil lour author devoted a chapter of Book II of the Treaty. Specifically, five chapters, the 13th to 17th (Say, 1804-1807, Tome II, pp. 270-336). 
commented that excess was harmful. Finally, he addressed the issue of paper money, analyzing their advantages and disadvantages and how it could not exceed the amount of gold and silver in circulation had, since its excess would be detrimental to the economy. In short, Dou reproduced the Smithian position on this matter.

\section{Edualdo Jaumeandreu i Triter (1774-1840)}

The friar Edualdo Jaumeandreu i Triter (1774-1840) began teaching the economy on February 14, 1814, in Palma de Mallorca (Jaumeandreu Triter, 1814a). After six months of teaching, the Junta de Comerciode Barcelona accepted his proposal for the creation of a chair of political economy at the institution (Jaumeandreu Triter, 1814b). He taught at this chair since August 29, 1814, until his death. During his experience, he published two works of economic character: Los rudimentos de economíapolítica (1816) and the Curso elemental de economíapolítica con aplicación a la legislacióneconómica de España (1836), both published in Barcelona and theoretical foundation based on Say.

Jaumeandreu wrote the Rudimentos as a dialogue with questions and answers, like Say had done in his Catéchisme (1815). The work was structured in books, parts, and chapters, and collected the same order as the first edition of Say's Traité (1803). He saw his five books: the production of currency, the value of things, income, and consumption. Regarding the number of chapters, the rudimentos had some less per book Traité, and sometimes incorporating a special chapter relating to Spain or Catalonia. In terms of content, this was very similar to Say, since many of the chapters in this book had the same title as the Traité and expounded the same ideas. It should be noted two issues that shown in the first part of the book production, did not match the statements of Say in his Traité; and not shared with the French economist idea of free trade without restrictions.

Jaumeandreu began his work with a preliminary lesson to explain the sources of wealth and four chapters grouped under the heading of the first part of the book first. In this block, explained the process of multiplication of the human species and the systems that had developed men to survive and provide for their needs, which could be reduced to three: absolute agriculture; agriculture in charge of the slaves; and on agriculture, founded on a system of manufactures. This explanation of the historicist evolution of socio-economic development of humanity was not original, but had been described by Herrenschwand (1728-1812) in De l'économiepolitiquemoderne. Discoursfondamental sur la population (1786), which was translated into Spanish by Juan Smith (1800). As regards to freedom of trade, indicated that proposed by Smith and Say was not applicable to Spain because of the degree of development of our country, which raised the protection of the incipient Spanish industry (Jaumeandreu Triter, 1816, pp. 113-120). However, he admitted the goodness of this freedom in fully developed countries.

The Curso Jaumeandreu was an evolution of its Rudimentos. This work could be considered as a second edition of the first, enlarged and corrected, as is generally annotated at that time. But abandon the use of dialogue, which was used in the previous work, and the addition of a second take dedicated to economic issues of Spain led to present it as a new work. On the first volume, and changes are reflected Say structure that had made in his Traité from the second edition ${ }^{14}$. To better match the scheme of Say, the author took the first part of the book production of its Rudimentos in the Curso, leaving the four initial chapters and preliminary lesson, as an introduction to the basics of science.

\footnotetext{
14 The second edition of the Traité (1814) grouped the books of the work top five in three. In particular, it distinguished the following books: production, distribution, and consumption.
} 
His first book was dedicated to production where he developed the ideas of Say, but with greater independence regarding the order. The chapters on the value of things, and currency, were separated from this book, forming the third work of Jaumeandreu ${ }^{15}$. Furthermore, the content of the second, the distribution of wealth, and the fourth consumption clearly show its link with the thought of Say ${ }^{16}$.

The second volume of this work, dedicated to Spain, allowed him to separate his ideological position regarding Say more clearly than in its Rudimentos. This volume, or separate part of Curso ${ }^{17}$, was divided into five books which analyzed the economic and trade legislation in Spain, its taxation and how to encourage both agricultural and industrial production. Throughout the text made references to several Spanish authors, he said aspects of the writings of Dou and Florez. Jaumeandreu kept in the Curso the same position as in their Rudimentos on the issue of full freedom in foreign trade, devoting the fourth chapter of the third of this book take to justify the reasons that prevented Spain to apply this principle, though defender freedom of internal trade.

Regarding the coin, Jaumeandreu respected the judgment and order that Say expounded in his Treatise, analyzing the concept of currency such as gold and silver were the best merchandise to be used as money, paper money, and operation of banking, etc.

\section{Conclusions}

Here are some tentative ideas on the subject outlines analyzed. Thus, it is noteworthy that Hutcheson's contributions to the debate on the currency are fundamental to the mentioned works. No significant differences on their concept, advantages and disadvantages of source are observed. The debate focuses more on the amount of money that must circulate in the economy, the definition of the value of things, and the use of paper money. In particular, there is unanimity that the currency promotes circulation, which promotes trade and therefore the wealth of nations. However, it is indicated that the coinage of a country could not exceed the value of their property, as this generated increased their price and medium term impoverishment of the country. Furthermore, the issue of paper money, that is the bank money, was not widely accepted, and all authors indicated that although made possible increased trade, thanks to credit it generated, always had to be supported with the same amount of gold and silver deposited on the issuing bank. Therefore, the authors studied still anchored in the concept of commodity money and did not deem it proper to the concept of money sign, which would allow increased exponentially credit and the start of economic duality between real and financial economy, until that moment, all the authors believe that this value cannot exceed the real economy.

The authors analyzed, a linear evolution is observed as to the subject and analyzed Say can be considered a great synthesizer. This author collects the ideas expressed by Francis Hutcheson and later disseminated by Antonio Genovesi and Adam Smith.

\footnotetext{
${ }_{15}$ Possibly Jaumeandreu decided this split, even if it meant breaking fidelity scheme of Say, three books, by increasing chapters Say conducted on this matter in its fifth edition (1826) and because, at that time, most of the books were published on the subject were to a division into four books. This new scheme was presented by James Mill (1773-1836) in the Elements of Political Economy (1821), which was translated into Spanish by Manuel Maria Gutierrez (1831). This work or publication in Spain by Alvaro Florez Estrada (1766-1853), Curso de Economíapolitica (1835), the first edition (1829) was published in London could influence the design of the Curso de Jaumeandreu. The similarities between the two works and the Jaumeandreu were more evident with the second work, with the first, as Florez was follower of the ideas of Say.

${ }^{16}$ Lluch and Almenar (2000, p. 112) point out that the main guide of Volume I of Curso by Jaumeandreu is the homonymous work by Florez Estrada. However, although clearly knew this work, it seems more plausible that has to guide the fifth French edition of Say's Traité, as there are many similarities between the indices of these works.

${ }^{17}$ He said that the difference of pages existed between the two volumes. The first volume was 390 pages, while the second did not exceed 155 pages.
} 
Finally, it indicates that among Spanish authors, their works reflected the doctrine taught by his contemporaries. Danvila observed the imprint of the ideas of Hutcheson and Genovesi. Dou was a follower of Smith. Finally, Jaumeandreu assimilated the model proposed by Say. These correlations indicate the proper degree of dissemination of European economic thought in our country between the late 18th and early 19th centuries.

\section{References}

Almenar Palau, S., \& Lluch Martín, E. (2000). Difusión e influencia de los economistas clásicos en España (1776-1871) [Dissemination and influence of the classical economists in Spain (1776-1871)]. In E. Fuentes Quintana (Ed.), Economía y economistas españoles, 4: La economía clásica (Economy and Spanish economists, 4: Classical economics) (pp. 93-170). Barcelona: Galaxia Gutenberg-Círculo de Lectores.

Astigarraga Goenaga, J., \& Usoz Otal, J. (2008). Del A. Genovesi napolitano de Carlo di Borbone al A. Genovesi español de Carlos III: la traducción española de las Lezioni di commercio de V. de Villava (A. Genovesi Neapolitan by Carlo di Borbone to A. Genovesi Spanish by Carlos III: The Spanish translation of the Lezioni V. di Commercio of Villava). Cuadernos de Historia del Derecho (Journal of Legal History), 15, 293-326.

Canard, N. F. (1801). Principes d'économie politique (Principles of political economy). Paris: Chez F. Buisson.

Canard, N. F. (1804). Principes d'économie politique (Principles of political economy). (F. Escolar y Serrano, Trans.). Madrid: Oficina de la Viuda de López e Hijos.

Castro-Valdivia, M. (2012). El pensamiento económico en la Cátedra de Economía Politica de la Universidad de Granada (1807-1842): personajes $e$ ideas (The economic thought in the chair of political economy at the University of Granada (1807-1842): Characters and ideas). University of Jaén, Jaén.

Cervera Ferri, P. (2008). Lecciones y lecturas de Bernardo Danvila (Lessons and readings of Bernardo Danvila). In B. J. Danvila Villarasa (Ed.), Lecciones de Economía Civil, o del Comercio por Bernardo J. Danvila y Villarrasa. MDCCXXIX. Estudio introductorio y edición anotada de Pablo Cervera Ferri (Lessons of civil economy or trade by Bernardo J. Danvila and Villarrasa. MDCCXXIX. Introductory study and annotated edition of Pablo Cervera Ferri) (pp. 10-76). Zaragoza: Institución "Fernando el Católico".

Condorcet, M. J. A. N. de C., \& Marquis de. (1792). Compendio de la obra Inglesa intitulada Riqueza de las Naciones, hecho por el marques de Condorcet, y traducido al castellano con varias adicciones del original, por don Carlos Martinez de Irujo (Bibliothèque de l'homme public, ou analyse raisonnée des principaux ouvragesfrançois et étrangers sur la politique en général, la législation, les finances, la police... par M. le Marquis de Condorcet..., M. de Peysonel..., M. Le Chapellier..., Paris: Buisson. 28 tomes. 1790-1792) (Compendium of English work entitled Wealth of Nations, by the Marquis de Condorcet....). (C. Martínez de Irujo, Trans.). Madrid: Imprenta Real.

Danvila Villarasa, B. J. (2008). Lecciones de Economía Civil, o del Comercio por Bernardo J. Danvila y Villarrasa. MDCCXXIX. Estudio introductorio y edición anotada de Pablo Cervera Ferri (Lessons of civil economy or trade by Bernardo J. Danvila and Villarrasa. MDCCXXIX. Introductory study and annotated edition of Pablo Cervera Ferri). Zaragoza: Institución "Fernando el Católico". (Original work published 1779).

Dou y Bassóls, R. L. de. (1817). La riqueza de las naciones, nuevamente explicada con la doctrina de su mismo investigador (The wealth of nations, explained again the doctrine of the same researcher) (Vol. 2). Cervera: Imprenta de la Pontifica y Real Universidad.

Florez Estrada, A. (1829). Curso de Economía Política, por D. Alvaro Florez Estrada (Course of economy policy, by D. Álvaro Flórez Estrada) (Vol. 2). Londres: D. M. Calero.

Florez Estrada, A. (1835). Curso de Economía Política, por D. Alvaro Florez Estrada. Cuarta edición corregida (Course of economy policy, by D. Álvaro Flórez Estrada) (Vol. 2, 4th ed.). Madrid: Imprenta de Miguel de Burgos.

Genovesi, A. (1765-1767). Delle Lezioni di Comercio o'ssia di Economia Civile. Da leggersi nella Cattedra Interiana dell'Ab. Genovesi, regio cattedratico. Parte prima. Per il primo semestre. in Napoli MDCCLXV. (Parte seconda. Per il secondo semestre. In Napoli MDCCLXVII) (Lesson of Comercio o'ssia of civil economy...) (Vol. 2). Napoli: Fratelli Simone.

Genovesi, A. (1768-1770). Delle Lezioni di Comercio o'ssia di Economia Civile. Da leggersi nella Cattedra Interiana dell'Ab. Genovesi, regio cattedratico. Parte prima. Per il primo semestre. Seconda edizione Napoletana. MDCCLXVIII. (Parte seconda. Per il secondo semestre. MDCCLXX) (Lesson of Comercio o'ssia of civil economy...) (Vol. 2). Napoli: Stamperia Simoniana. 
Genovesi, A. (1785-1786). Lecciones de comercio, ó bien de Economía civil del abate Antonio Genovesi, Catedrático de Nápoles. Traducidas del italiano por Don Victorian de Villava, Colegial Mayor de San Vicente Mártir de la Universidad de Huesca, y Catedrático de Código de la misma (Lesson of Comercio o'ssia of civil economy...). Tome primero. Madrid MDCCXXXLV (Tome segundo. Madrid MDCCXXXLV/Tome tercero. Madrid MDCCXXXLVI) (Delle Lezioni di Comercio o'ssia di Economia Civile. Napoli: Stamperia Simoniana. 1768-1770) (Vol. 3). (V. de Villava, Trans.). Madrid: D. Joachin Ibarra (Tome tercero. Viuda de Ibarra, hijos y compañía).

Genovesi, A. (1804). Lecciones de comercio, ó bien de Economía civil del abate Antonio Genovesi, Catedrático de Nápoles. Traducidas del italiano por Don Victorian de Villava, Colegial Mayor de San Vicente Mártir de la Universidad de Huesca, y Catedrático de Código de la misma (Lesson of Comercio o'ssia of civil economy...). (Delle Lezioni di Comercio o'ssia di Economia Civile. Napoli: Stamperia Simoniana. 1768-1770) (V. de Villava, Trans.). Madrid: Imprenta de Don José Collado. 3 tomos. [Reimpresión de la edición de 1785-1786].

Herrenschwand, J. (1786). De l'économie politique moderne. Discours fondamental sur la population (Of modern political economy. Fundamental discourse on population). Londres: Chez T. Hookham.

Herrenschwand, J. (1800). Principios de economía política, por Herrenschwand, traducidos del francés al castellano por don Juan Smith, Brigadier de de la Real Armada (Principles of political economy, by Herrenschwand, translated from French into Spanish by don Juan Smith, Brigadier of the Royal Navy). De l'économie politique moderne. Discours fondamental sur la population (Of modern political economy. Fundamental discourse on the population) (J. Smith, Trans.). Madrid: Imprenta de Vega y compañía.

Hutcheson, F. (1755). A system of moral philosophy, in three books: Written by the late Francis Hutcheson, L. L. D., Professor of Philosophy in the University of Glasgow, published from the original manuscript, by his son Francis Hutcheson, M. D. To which is prefixed some account of the life, writings, and character of the author by the reverend William Leechman, D. D., Professor of Divinity in the same university (Vol. 2). Glasgow and London: R. and A. Foulis \& A. Millar and T. Longman.

Jaumeandreu Triter, E. (1814a). Oración inaugural, que en la abertura de la Cátedra de Economía Civil establecida en la ciudad de Palma por la Diputación Provincial de Mallorca, dixo el día 14 de febrero de1814 el P. Fr. Edualdo Jaumeandreu, de la orden de S. Agustín, profesor de dicha ciencia nombrado por la misma diputación (Inaugural prayer, which in the opening of the chair of civil economy established in the city of Palma by the Diputación Provincial de Mallorca, said on February 14 , 1814, P. Fr. Edualdo Jaumeandreu, of the order of S. Augustine, said science teacher appointed by the same provincial). Palma: Imprenta de Miguel Domingo.

Jaumeandreu Triter, E. (1814b). Oración inaugural, que en la abertura de la Cátedra de Economía Política establecida en la ciudad de Barcelona por la Real Junta de Comercio del principado de Cataluña, dixo el Padre Fray Edualdo Jaumeandreu, del orden de San Agustín, catedrático de la misma, el dia 29 de agosto de 1814 (Inaugural prayer, which is in the opening of the chair of political economy established in the city of Barcelona by the Royal Board of Commerce of the Principality of Catalonia, said father Fray Edualdo Jaumeandreu, of the order of Saint Augustine, professor of the same, on August 29, 1814). Barcelona: Oficina de D. Antonio Brusí.

Jaumeandreu Triter, E. (1816). Los rudimentos de economía politica (The rudiments of political economy). Barcelona: Oficina de D. Antonio Brusí.

Jaumeandreu Triter, E. (1836). Curso elemental de economía política con aplicación a la legislación económica de España (Basic course in political economy with application of economic legislation Spain) (Vol. 2). Barcelona: Imprenta de Gaspar.

Mill, J. (1821). Elements of political economy. London: Baldwin, Cradock, and Joy.

Mill, J. (1831). Elementos de economía política por J. Mill, autor de la historia de la India. Puestos en castellano por D. Manuel Maria Gutierrez (Elements of political economy by J. Mill, author of the history of the India. Jobs in Spanish by D. Manuel María Gutierrez). (M. M. Gutiérrez, Trans.). Madrid: Imprenta de D. Miguel de Burgos.

Rothbard, M. N. (1995). An Austrian perspective on the history of economic thought. Vol I: Economic thought before Adam Smith. Cheltenham \& Vermont: Edward and Elgar Publishing Limited.

Say, J. B. (1803). Traité d'économie politique, ou Simple exposition de la manière dont se forment, se distribuent et se consomment les richesses. Par Jean-Baptiste Say, membre du Tribunat (Treaty of political economy, or simple exposure of the manner in which form, distribute and to consume resources. By Jean-Baptiste Say, member of the Tribunat) (Vol. 2). Paris: De l'Imprimerie de Crapelet. Chez Deterville, Libraire.

Say, J. B. (1804-1807). Tratado de Economía politica o exposición simple del modo como se forman, distribuyen y consumen las riquezas, escrito en francés por Juan Bautista Say, y traducido al castellano por... (Treaty of political economy or simple mode exposure as they form, distribute and consume wealth, written in French by John Baptist Say, and translated into Spanish by...). (J. Queipo de Llano, Trans.). Madrid: Oficina de Pedro María Caballero. 
Say, J. B. (1814). Traité d'économie politique, ou Simple exposition de la manière dont se forment, se distribuent et se consomment les richesses; Seconde édition entièrement refondue et augmentée d'un épitomé des principes fondamentaux de l'économie politique. Par Jean-Baptiste Say, ex-membre du Tribunat (Treaty of political economy, or simple exposure of the manner in which form, distribute and to consume wealth; second edition fully revised and augmented to an epitome of the the economy policy. By Jean-Baptiste Say, former member of the Tribunat) (Vol. 2). Paris: De l'Imprimerie de Crapelet, Chez Antonie-Augustin Renouard.

Say, J. B. (1815). Catéchisme d'économie politique, ou Instruction familière qui montre de quelle façon les richesses sont produites, distribuées et consommées dans la société; Ouvrage fondé sur les faits, et utile aux différentes classes d'homes, en ce qu'il indique les avantages que chacun peut retirer de sa position et de ses talens. Par Jean-Baptiste Say, Auteur du Traité d'Économie politique (Catechism of political economy, or familiar statement that shows how resources are produced, distributed and consumed in the society; Book based on the facts, and useful to different classes d'homes in this qu'il shows the benefits that each can withdraw its position and its talens. By Jean-Baptiste Say, author of the d'economie policy). Paris: De l'Imprimerie de Crapelet, Chez Delaunay, Libraire.

Say, J. B. (1826). Traité d'économie politique, ou Simple exposition de la manière dont se forment, se distribuent et se consomment les richesses; Cinquième édition, augmentée d'un volume, et à laquelle se trouvent joints un épitomé de principes fondamentaux de l'économie politique et un index raisonné de matières; par Jean-Baptiste Say, Chevalier de Saint-Wolodomir, membre de l'Académie impériale des Sciences de Saint-Pétersbourg, de l'Académie royale des Sciences de Naples, de celle Stockholm, de la Société Royale de Madrid, de celles de Cordoue et d'Avila, de celle de Zurich, etc.; Professeur d'Économie industrielle au Conservatoire royal de Arts et Métiers de Paris (Treaty of political economy, or simple exposure of the manner in which form, distribute and to consume wealth; Fifth edition, volume, and to which are attached an epitome of fundamental principles of political economy and an index raisonné of materials; by Jean-Baptiste Say, Chevalier de Saint-Wolodomir, member of Imperial l'academie des Sciences de Saint-Pétersbourg, of Royal l'academie of Sciences of Naples, from Stockholm, the Royal Society of Madrid, Cordoba and d'Avila, from Zurich, etc.; professor of industrial d'economie at the Royal Conservatory of Arts and Crafts in Paris) (Vol. 3). Paris: Imprimerie de Casimir, Chez Rapilly, Libraire.

Smith, A. (1776). An inquiry into the nature and causes of the wealth of nations (Vol. 2). London: W. Strahan and T. Cadell.

Smith, A. (1794). Investigación de la naturaleza y causas de la riqueza de las naciones. Obra escrita en Inglés por Adam Smith, Doctor en Leyes, é Individuo de la Real Sociedad de Londres y de Edimburgo: Comisario de la Real Hacienda en Escocia: y profesor de Filosofía Moral en la Universidad de Glasgow. La traduce al castellano el Lic. D. Josef Alonso Ortiz, con varias Notas é Ilustraciones relativas á España (Research of the nature and causes of the wealth of nations. Work written in English by Adam Smith, Doctor of Laws, individual of the Royal Society of London and Edinburgh: Commissioner of the Royal Treasury in Scotland, and Professor of Moral philosophy at the University of Glasgow. Translate it to Spanish Lic. D. Josef Alonso Ortiz, with several Notes and illustrations relating to Spain). An inquiry into the nature and causes the wealth of nations (Vol. 3, 7th ed.). (J. Alonso Ortiz, Trans.). Valladolid: Oficina de la Viuda e hijos de Santander.

Smith, A. (1805-1806). Investigación de la naturaleza y causas de la riqueza de las naciones. Escrita en Inglés por el Dr. Adam Smith, Y traducida al castellano por el Lic. D. Josef Alonso Ortiz, con varias Notas y Ilustraciones relativas á España. Segunda edición muy corregida y mejorada (Research of the nature and causes of the wealth of nations. Written in English by Dr. Adam Smith, and translated into Spanish by LIC. D. Josef Alonso Ortiz, with several notes and illustrations relating to Spain. Second edition corrected and very improved). An inquiry into the nature and causes the wealth of nations (Vol. 3, 7th ed.). (J. Alonso Ortiz, Trans.). Valladolid: Oficina de la Viuda e hijos de Santander.

Soubeyroux, J. (1995). El Real Seminario de Nobles de Madrid y la formación de las elites en el siglo XVIII (Real Noble Seminary of Madrid and the formation of elites in the eighteenth century). Bulletin Hispanique (Hispanic Bulletin), 97(1), 201-212. 